\title{
Changes in guava (Psidium guajava L. var. Paluma) nectar volatile compounds concentration due to thermal processing and storage
}

\author{
Alterações na concentração de compostos voláteis de néctar de goiaba \\ (Psidium guajava L. var. Paluma) devido ao processamento térmico e à estocagem
}

\author{
Maria Ivaneide Coutinho CORREA ${ }^{1}$, Jose Benicio Paes CHAVES $^{1 *}$, Gulab Newandram JHAM², \\ Afonso Mota RAMOS ${ }^{1}$, Valéria Paula Rodrigues MINIM ${ }^{1}$, Silvia Rosane Colodeti YOKOTA ${ }^{1}$
}

\begin{abstract}
Guava nectars were formulated for approximately 10,12 , or $14^{\circ}$ Brix, with $40 \%$ guava pulp. Sodium benzoate, 500 mg.kg ${ }^{-1}$ was used as preservative. The Brix value was adjusted with saturated sucrose syrup. The guava nectar was pasteurized $\left(85^{\circ} \mathrm{C} / 42 \mathrm{~seconds}\right)$ in tubular heat exchanger and then hot filled in $500 \mathrm{~mL}$ white glass bottles. The products were stored either at room temperature $\left(25 \pm 5^{\circ} \mathrm{C}\right)$ or refrigerated $\left(5 \pm 2{ }^{\circ} \mathrm{C}\right)$ under fluorescent light exposure and analyzed on the day after processing (time zero) and also 40, 80 , and 120 days of storage. Eight compounds were identified and quantified by Gas Chromatography (GC) -Mass Spectrometry (MS): hexanal, (E)-hex-2-enal, 1-hexenol, $(Z)$-hex-3-enol, (Z)-hex-3-enyl acetate, phenyl-3-propyl acetate, cinnamyl acetate, and acetic acid. There was no significant effect of thermal treatment on the volatile compound concentrations, except for a significant decrease $(\mathrm{p}=0.0001)$ in hexanal and $(Z)$-hex-3-enyl acetate $(\mathrm{p}=0.0029)$. As for the storage time, there was a much greater decrease in the esters contents, such as $(Z)$-hex-3-enyl and phenyl-3-propyl acetates. Cinnamyl acetate had the greatest decrease over storage time. Refrigeration was better than room temperature for guava nectar volatile compounds stability over storage time, mainly for esters compounds, which are important for the product aroma and flavor.

Keywords: guava nectar; volatile compounds; GC; GC/MS; thermal processing; storage.
\end{abstract}

\section{Resumo}

Néctares de goiaba foram formulados para 10, 12 ou $14^{\circ}$ Brix. Benzoato de sódio, $500 \mathrm{mg} . \mathrm{kg}^{-1}$, foi usado como conservante. O Brix foi ajustado usando xarope saturado de sacarose. O néctar foi pasteurizado a $85^{\circ} \mathrm{C} / 42$ segundos, em trocador de calor tubular e envasado, a quente, em garrafas de vidro branco de $500 \mathrm{~mL}$. Os produtos foram estocados à temperatura ambiente $\left(25 \pm 5^{\circ} \mathrm{C}\right)$ e sob refrigeração $\left(5 \pm 2{ }^{\circ} \mathrm{C}\right)$, expostos à luz fluorescente e analisados um dia após processamento (tempo zero) e aos 40, 80 e 120 dias de estocagem. Oito compostos foram identificados e quantificados por Cromatografia Gasosa (CG) - Espectrometria de Massa (EM): hexanal, (E)-hex-2-enal, 1-hexenol, (Z)-hex-3-enol, acetato de (Z)-hex-3-enila, acetato de 3-fenilpropila, acetato de cinamila e ácido acético. O efeito do processamento térmico na concentração de compostos voláteis não foi significativo, exceto um decréscimo na concentração de hexanal $(\mathrm{p}=0,0001)$ e acetato de (Z)-hex-3-enila $(\mathrm{p}=0,0029)$. Observou-se maior decréscimo no teor dos ésteres $(Z)$-hex-3-enila e acetato de 3-fenilpropila durante a estocagem. $\mathrm{O}$ acetato de cinamila apresentou maior decréscimo de concentração após a estocagem. A refrigeração apresentou melhor efeito na estabilidade dos teores de voláteis, principalmente os ésteres.

Palavras-chave: néctar de goiaba; compostos voláteis; GC; GC/MS; processamento térmico; estocagem.

\section{Introduction}

Aroma is one of the most important factors in sensory quality identity for fruits and vegetable products. Food aroma can be understood and identified by its volatile chemical compounds content. These volatiles are sensed and the aroma perceived by olfactory sensory receptors either when food are tasted or by its smell exhaled from a distance (NOBREGA, 2003).

Volatile compounds have an important role in fruit juice sensory quality, particularly when it is heat treated and need to be stored (EL-NEMR; ISMAIL; ASKAR, 1988). Qualitative and quantitative analyses of aroma compounds are needed in monitoring product quality and for aroma developing in fresh and processed products (SONG et al., 1997).

Yen and Lin (1999), studying heat treatment, $95^{\circ} \mathrm{C} / 5$ minute, in guava juice, detected a decrease in the volatile compounds content as compared to fresh product; however, there was no important effect of storage time on the volatile concentration up to 60 days under refrigeration at $4{ }^{\circ} \mathrm{C}$. Esters and alcohols had higher concentrations than those of the other volatile compounds.

Recebido para publicação em 13/1/2009

Aceito para publicação em 20/6/2009 (004027)

${ }^{1}$ Departamento de Tecnologia de Alimentos, Universidade Federal de Viçosa - UFV, CEP 36570000, Viçosa - MG, Brasil, E-mail: jbchaves@ufv.br

${ }^{2}$ Departamento de Química, Universidade Federal de Viçosa - UFV, CEP 36570-000, Viçosa - MG, Brasil

${ }^{*}$ A quem a correspondência deve ser enviada 
Clara et al. (1999) detected 77 volatile compounds in red guava pulp with higher concentrations for the C6 aldehydes (E)-hex-2-enal and hexanal and, tetradecane hydrocarbon. Ortega et al. (1998) analyzed volatile compounds in guava of four varieties and found that limonene, $\beta$-caryophyllene, ethyl hexanoate and acetate, $(Z)$ and $(E)$-hex-2-enal, $\beta$-ionone, and (Z)-hex-3-enol were predominant.

Tolulemonde and Beauvererd (1985 apud ORTEGA; PINO, 1996), identified 115 chemical compounds and found that hexanal, (E)-hex-2-enal, ethyl hexanoate, and hexyl acetate are the most important compounds for guava aroma. Shibamoto and Tang (1990) considered methyl benzoate, 2-phenylethyl acetate, and cinnamyl acetate as the major compounds for the guava pleasant aroma. Cinnamyl acetate has a more intense sweet floral aroma.

Askar, El-Nemr and Bassiouny (1986) suggested that guava aroma is mainly due to cinnamyc derivatives, C6 aldehydes, and $\beta$-caryophyllene. Pino, Marbot and Vasques (2002) reported that the presence of aliphatic and terpenic compounds is thought to be the main contributor to the unique guava flavor. They worked on volatiles in Costa Rican guava fruit by a simultaneous steam distillation-solvent extraction method and found one hundred and seventy five compounds identified in the aroma concentrate by GC-sniffing technique.

Jordan et al. (2003), in a study characterizing guava fresh fruit puree aromatic profile by GC-MS, reported the quantification of 51 compounds. The volatile profile of guava fresh fruit puree has been characterized by the presence of terpenic hydrocarbons and 3-hydroxi-2-butanone as quantitatively the major components. In the olfatometric analysis, 48 active aroma components were detected by the panelists. 3-penten-2-ol, and 2-butenyl acetate were claimed to be reported for the first time as active aroma constituents of pink guava puree.

Ideally, sample preparation techniques should be rapid, easy to use, low cost, and compatible with several analytical instruments. Solid Phase Micro Extraction (SPME) is a sample preparation technique for gas chromatography quantitative and qualitative analyses which is simple, rapid, sensitive, does not use solvents, and needs very small sample volumes. This technique is relatively low cost and easy of automation. An efficient extraction of chemical compounds is dependent on time, stirring, heat, $\mathrm{pH}$ and salt, and $\mathrm{NaCl}$ concentration (KATAOKA; LORD; PAWLISZYN, 2000). The SPME technique is based on chemical compound adsorption on a silica fiber covered by a stationary phase. The fiber is immersed in an aqueous sample (immersion SPME) or the fiber is exposed to the sample headspace (headspace SPME) (Valente and Augusto, 2000; Bjelen et al., 1998). SPME together with gas chromatography make possible a rapid identification of volatile compounds and may be appropriate for industrial processing monitoring. It provides high reproductibility and it is not affected by the presence of water in the sample. This technique, widely used in food analysis, is useful for quality control in monitoring efficiency of chemical processes and manufacturing (BENE et al., 2001).
Nilsson, Ferrari and Facchetti (1997) in a study of analysis validating for volatile compounds quantification in aqueous sample by SPME extraction, reported adequate linearity, repeatability, reproductibility, and limit of detection in the range of ng. $\mathrm{L}^{-1}$.

Consumers prefer better quality products. In this context, those food and beverages with an edge in sensory quality shall be preferred. Consequently, studies on aroma attributes for food and beverages are growing. Those studies focus on understanding why sensory attributes, such as aroma change with processing and storage. This knowledge is leading to quality improvement of ready to drink fruit juice (SHAW; BERRY, 1976). More detailed studies are needed on effect of processing and time and conditions of storing on sensory quality of ready to drink fruit juices produced in Brazil. Guava tree presents agronomic and variety features of tropical countries and guava fruit from Paluma variety, with its red pulp, has excellent industrial traits for processing (MANICA et al., 2000). Guava from Paluma variety is the most used in commercial guava plantations in Brazil for industry use.

This study aimed to identify and quantify some volatile compounds in heat treated guava nectar and also to verify changes due to heat treatment and storage under room temperature, $25 \pm 5^{\circ} \mathrm{C}$, or under refrigeration, $5 \pm 2{ }^{\circ} \mathrm{C}$, for up to 120 days.

\section{Material and methods}

\subsection{Material}

Guava nectar was produced from the pulp of ripe guava (Psidium guajava L.) of Paluma variety, adequate stage for nectar processing. About $200 \mathrm{~kg}$ of fruits were acquired from a farm called "Tropical" in the city of Visconde do Rio Branco, Minas Gerais State, and kept under refrigeration, $5 \pm 1{ }^{\circ} \mathrm{C}$, for four days before processing.

\subsection{Methods}

\section{Guava nectar processing}

Guava fruits were manually selected and washed with jets of chlorinated water and 5 to $10 \mathrm{mg} . \mathrm{L}^{-1}$ of active chlorine. Pulping was done in knife type disintegrator "TECNINT", model TUF02, cylindrical beater and two stage pulping "TECNINT", model DMF-04; the first stage with a $0.5 \mathrm{~mm}$ and the second one with a $0.3 \mathrm{~mm}$ sieve for refining and finishing the guava pulp. Next, sodium benzoate, used as preservative, was added, $500 \mathrm{mg} \cdot \mathrm{kg}^{-1}$, under constant manual stirring in a $100 \mathrm{~L}$ capacity stain steel tank and, then sent to a tubular pasteurizer. The guava pulp was pasteurized in multitubes "TECNINIT" PTU-02 model, at $85^{\circ} \mathrm{C} / 42$ seconds and, then cooled down to $25^{\circ} \mathrm{C}$ in a multitube heat exchanger "TECNINIT" PTU-02 model. The temperature heat treatment was determined based on a research by TchangoTchango et al. (1997). The pasteurized guava pulp was kept in stain steel vessels in a refrigerated chamber, $5 \pm 1{ }^{\circ} \mathrm{C}$, for not more than five days before processing. Guava pulping and nectar formulation were done in a pilot unit fruit processing of "Escola Agrotécnica Federal de Rio Pomba", in the State of Minas Gerais. 
Guava nectar was formulated to be 10,12 , or $14^{\circ}$ Brix. Nectar formulation was done in $50 \mathrm{~L}$ batches by adding water and/or $40 \%$ sucrose syrup to refined guava pulp. Eight batches were prepared, since 10 and $14^{\circ}$ Brix guava nectar, it was prepared in three replications and, $12^{\circ}$ Brix guava nectar was done in two replications. The mixture was prepared by hand stirring in $100 \mathrm{~L}$ stain steel vessels. From each nectar batch, $2.1 \mathrm{~L}$ aliquot were withdrawn and separated as a control, not pasteurized. The other 47.9 L were heat pasteurized. Pasteurization was done in a tubular pasteurizer “TECNINT”, model PTU-02. Temperaturetime heat treatment was also $85^{\circ} \mathrm{C} / 42$ seconds. This binomial was determined based on a research by Tchango-Tchango et al. (1997). Following pasteurization, guava nectar was conveyed trough pasteurizer tubular outlet to a semi-automatic filler TECNINT, model DLP-02 and hot filled and caped into $500 \mathrm{~mL}$ transparent glass bottles. The bottles were turned upside down and kept in this position for 3 minutes for cap sterilization. After cap treatment, the bottles were cooled down in a tank with $40 \pm 5^{\circ} \mathrm{C}$ water for 10 minutes and then placed in another tank with $20 \pm 5^{\circ} \mathrm{C}$ water for 10 minutes, completing guava nectar cooling.

For each of the eight groups of nectar, 160 bottles were prepared. Half of those was stored under refrigeration, $5 \pm 2{ }^{\circ} \mathrm{C}$, for 120 days under $20 \mathrm{~W}$ fluorescent light. This was supposed to be similar to the conditions in retail stores. The remaining 80 bottles were stored at room temperature, $25 \pm 5{ }^{\circ} \mathrm{C}$, under natural light since the room windows were clean clear glass. The analyses were performed on the day following processing (time zero) and 40, 80, and 120 days after processing.

\section{Solid phase micro extraction}

Samples of guava nectar stored for 120 days, either at room temperature, $25 \pm 5^{\circ} \mathrm{C}$ or under refrigeration, $5 \pm 2{ }^{\circ} \mathrm{C}$, were prepared for chromatographic analysis on the day after processing (time zero) and 40,80, and 120 days of storage. The samples were centrifuged for 8 minutes, $3.600 \times \mathrm{g}$, in a FANEM centrifuge, model Excelsa II - 205N (MORALES, 1999).

The chemical compounds to be analyzed were extracted from $3 \mathrm{~mL}$ of supernatant from centrifugation and added of $0.6 \mathrm{~g}$ of $\mathrm{NaCl}$ p.a. in a $4.5 \mathrm{~mL}$ glass tube with a silicone film cap. The immersion SPME extraction technique was used, as described by Yang and Peppard (1994). A hand holder SPME probe and fibers with polidimethylsiloxane in a SUPELCO $100 \mu \mathrm{m}$ film was used. The extraction conditions were 25 minutes of fiber immersion in the sample, at constant hand stirring, and 10 minutes of desorption injector time, at $270{ }^{\circ} \mathrm{C}$.

\section{Chromatographic analyzes: volatile compounds identification and quantification}

Eight chemical compound standards were used: aldehydes [hexanal; (E)-hex-2-enal], alcohols [hexanol; (Z)-hex-3-enol], esters [cinnamyl acetate; 3-phenylpropyl acetate; $(Z)$-hex3-enila] acetate and acetic acid. International Flavor and Fragrances (IFF) standards were used, except for acetic acid, from SUPELCO.
The volatile compounds identification was done by GC-MS in a SHIMADZU, model GCMS-QP5000. The volatile quantification was carried out by Gas Chromatography in a SHIMADZU, model G1-C7A, equipped with a FID. The volatiles were identified by comparison with the GC/MS-QP5000 library using retention time of standards for confirmation. Four point calibration curves, with $\mathrm{R}^{2}$ varying from 0.94 to 0.99 of external standards, were used for quantification purposes. The four-point calibration curves were obtained by split ratio varying from [split less-(blank-water); split (1:150); split (1:60); split (1:40)], with chemical standards aqueous solution at the following concentrations: $8.50 \mu \mathrm{L} .3 \mathrm{~mL}^{-1}$ for 3-phenylpropyl acetate, $4.00 \mu \mathrm{L} .3 \mathrm{~mL}^{-1}$ for hexanal, and $10.00 \mu \mathrm{L} .3 \mathrm{~mL}^{-1}$ for the others ((E)-hex-2-enal], alcohols [hexanol; (Z)-hex-3-enol], esters [cinnamyl acetate; (Z)-hex-3-enyl] acetate, and acetic acid). The chromatographic conditions for the standards were similar to those of the samples. Regression adjustment of calibration curves were forced to pass by origin. Blank readings were set to zero as reported by several researchers (NILSSON; FERRARI; FACCHETTI, 1997).

The identification and quantification of the volatiles were made by using the same column SUPELCOWAX 10 (30 $\mathrm{m} \times 0,25$ i.d, $0,25 \mu \mathrm{m}$, SUPELCO, $100 \mathrm{kPA}$ pressure and $40{ }^{\circ} \mathrm{C} / 2$ minutes temperature and, $5{ }^{\circ} \mathrm{C} /$ minutes to $210{ }^{\circ} \mathrm{C} / 20$ minutes programming temperature, totaling 56 minutes run. The chromatographic conditions were: $\mathrm{N}_{2}$ as running gas, flow rate $1.48 \mathrm{~mL} /$ minute, flame gas $\mathrm{H}_{2}$ and oxygen; split less injection, injector temperature $270{ }^{\circ} \mathrm{C}$; detector temperature $300{ }^{\circ} \mathrm{C}$. GC/MS conditions were: $\mathrm{H}_{2}$ as running gas, flow rate $1.48 \mathrm{~mL} /$ minute, scan range $\mathrm{PM}$ from 40 to 230; split less injection, injector temperature $279^{\circ} \mathrm{C}$; and detector temperature $280^{\circ} \mathrm{C}$.

\section{Statistical analyses}

The data, at time zero, were analyzed according to a factorial arrangement with two factors, 3 formulations: 10, 12, and $14{ }^{\circ}$ Brix and two treatments, pasteurized and not pasteurized nectar. Formulations 10 and $14^{\circ}$ Brix had three replications, and that of $12^{\circ}$ Brix had two. For analysis of variance purposes, it was treated as a factorial arrangement in a completely randomized design. The statistical model had three factors: 3 formulations 10, 12 and $14^{\circ}$ Brix, two storage temperatures (refrigerated and at room temperature) and three storage times (40, 80, and 120 days). For analysis of variance purposes, it was treated as a split plot arrangement with nectar formulation and storage temperature in a factorial arrangement completely randomized in main plots and storage time in the subplots. Only the pasteurized nectar was stored. Statistical analyses were run by using procedures of SAS (STATISTICAL ANALYSES SYSTEM, 1995), version 9.1, licensed to Federal University of Viçosa.

\section{Results and discussion}

\subsection{Identification and quantification of guava nectar volatile compounds}

Figure 1 is a typical chromatogram for a mix of the eight volatile chemical compounds standards proposed 
for identification and quantification. Figure 2 is a typical chromatogram, showing retention times $\left(r_{t}\right)$ for each of the eight chemicals, for a $10^{\circ}$ Brix guava nectar sample.

The detection of hexanal, (E)-hex-2-enal, $(Z)$-hex-3-enyl acetate, hexanol, $(Z)$-hex-3-enol, acetic acid, 3-phenylpropyl acetate, and cinnamyl acetate is presented in Figure 1. Figure 2 shows higher picks, 1 and 7, which correspond to hexanal and 3 -phenylpropyl acetate, respectively. These values may show that these compounds prevailed in the sample. The C6 compounds group, hexanal, (E)-hex-2-enal, hexanol, $(Z)$-hex-3-enol and the esters $(Z)$-hex-3-enyl acetate, 3-phenylpropyl acetate, and cinnamyl acetate identified in the guava nectar sample confirm the findings of other researchers, who consider these compounds as predominant in guava fruit and its products.

Idstein and Schreier (1985) also found these eight compounds in Brazilian guava and reported over $50 \%$ of volatile compounds as being aldehydes. They reported hexanal and (E)-hex-2-enal as being quantitatively predominant. Yen and Lin (1999) reported esters as major volatile compounds and responsible for pleasant intense fruity and sweet floral aromas in guava juice. They suggested these compounds as biogenetic derivatives of fatty acids $\beta$-oxidation, followed by alcohols. Yen, Lin and Yang (1992) determined volatile compounds in guava purée stored at low (frozen) temperature and compared with unprocessed fruit. They reported similar chromatographic profile for both guava purée after six months under freezing condition and unprocessed fruit. Twenty seven volatile compounds were reported, with (E)-hex-2-enal being present ing much greater amount. Nishimura et al. (1989), analyzing red pulp fresh guava and guava purée samples, also reported higher amounts of $\mathrm{C}_{6}$ chemical compounds. Among them, are the aldehydes (E)-hex-3-enal, (Z)-hex-3-enal, (E)-hex-2-enal and $(Z)$-hex-2-enal, accounting for $34 \%$ of total aldehydes followed by alcohols and acids.
Ortega and Pino (1996) in a comprehensive literature review on guava volatile compounds considering guava, pulp and guava puree, individually, reported the aldehydes, specially the $\mathrm{C}_{6}$ group, as important for guava aroma. They also considered the cinnamyc derivatives as possible contributors to balsamic aroma note perceived in ripe guava. Esters are predominant for sweet floral aroma.

\subsection{Identification and quantification of guava nectar volatile compounds: heat treatment effect - time zero}

Figure 3 is a typical gas chromatographic profile of guava nectar samples before (black) and after (gray) heat treatment. Table 1 summarizes the analysis of variance of volatile compounds content in guava nectar at time zero, no storage.

It can be seen in Figure 1 that in the control sample, $10{ }^{\circ}$ Brix, 1-C, all eight picks analyzed decreased in intensity after pasteurization, as compared to the same sample, not pasteurized. This decrease was higher, especially for pick 1 (hexanal) and pick $3((Z)$-hex-3-enyl acetate). The analysis of variance of volatile compounds content at time zero, Table 1, did not detect significant effect of interaction formulation $\times$ heat treatment $(p>0.05)$ for any of the compounds in guava nectar. Even though there seems to be a decrease in the volatile compounds concentration due to heat treatment, as shown in a typical chromatogram, Figure 3, the analysis of variance, Table 1, only detected significant difference $(\mathrm{p}<0.01)$ for hexanal, pick 1 and, (Z)-hex-3-enyl acetate, pick 3.

Losses of volatile compounds due to pasteurization, even in small amounts, are important from product aroma standpoint. Furthermore, cooked flavor can be developed in the product as a consequence of heat treatment (FELLOWS, 1997).

Table 1. Summary of the analysis of variance (Mean Square SV/Mean Square of Error) of volatile compounds content in guava nectar at time zero of storage*.

\begin{tabular}{cccc}
\hline Compound/SV & Form & Heat treatment & Form $\times$ heat \\
\hline DF & 2 & 1 & 2 \\
\hline Hexanal & $7.9131 / 5.9868$ & $309.6192 / 5.9868$ & $11.6885 / 5.9868$ \\
& $(0.3095)$ & $(0.0001)$ & $(0.1924)$ \\
(E)-hex-2-enal & $0.4973 / 0.0463$ & $0.0002 / 0.0463$ & $0.0087 / 0.0463$ \\
& $(0.0032)$ & $(0.9487)$ & $(0.8307)$ \\
Hexanol & $0.0021 / 0.0041$ & $0.0037 / 0.0041$ & $0.0082 / 0.0041$ \\
& $(0.6172)$ & $(0.6300)$ & $(0.1846)$ \\
(Z)-hex-3-enol & $0.0033 / 0.0023$ & $0.0030 / 0.0023$ & $0.0004 / 0.0023$ \\
(Z)-hex-3-enyl acetate & $(0.2835)$ & $(0.2808)$ & $(0.8363)$ \\
& $0.2082 / 0.0451$ & $0.6812 / 0.0451$ & $0.0246 / 0.0451$ \\
3-fenylpropil acetate & $(0.0380)$ & $(0.0029)$ & $(0.5959)$ \\
Cinnamyl acetate & $0.6134 / 1.0066$ & $0.0021 / 1.0066$ & $0.5723 / 1.0066$ \\
Acetic acid & $(0.5627)$ & $(0.9645)$ & $(0.5836)$ \\
& $0.0101 / 0.0274$ & $0.0471 / 0.0274$ & $0.0086 / 0.0274$ \\
\end{tabular}

${ }^{\star}$ Numbers in parenthesis are $\mathrm{p}$ value of $\mathrm{F}$ statistic. 


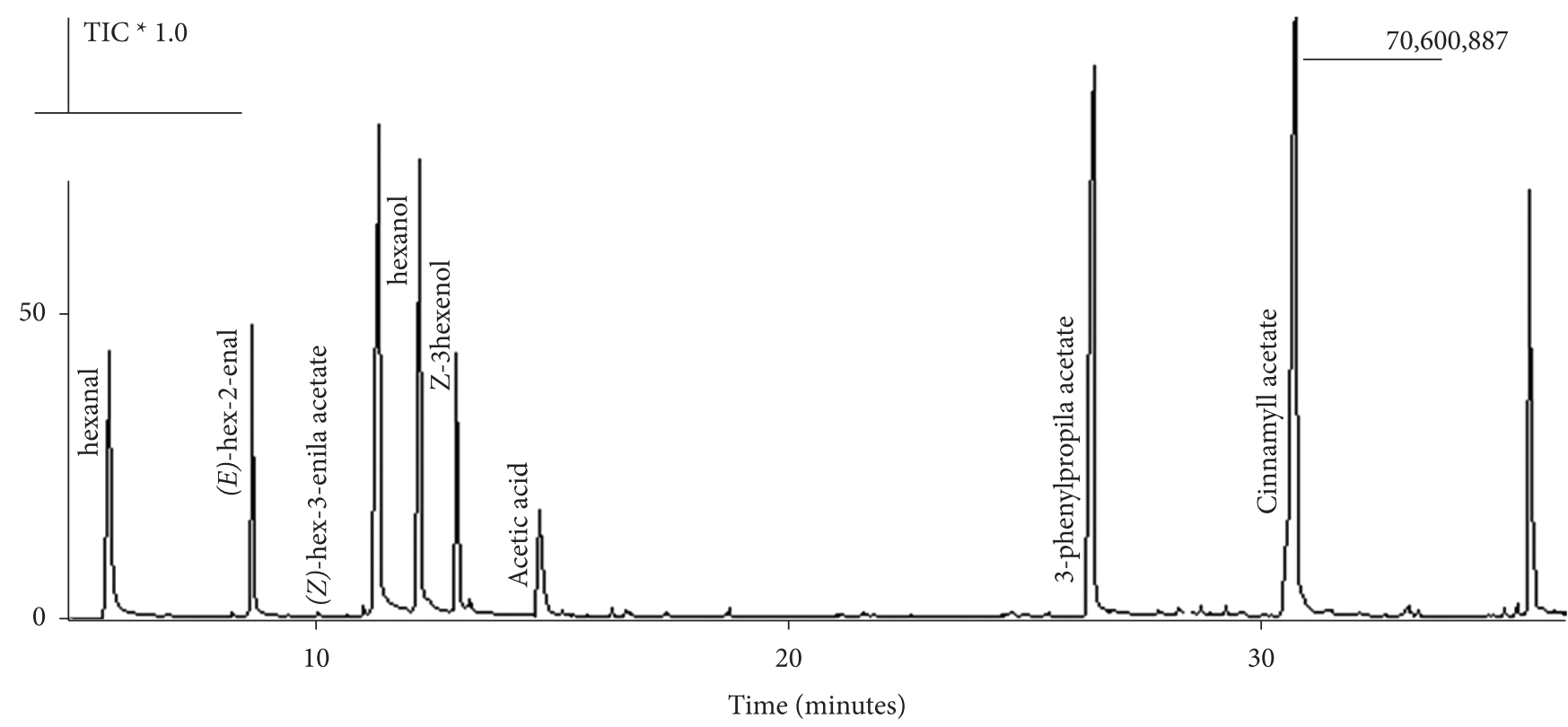

Figure 1. Typical chromatogram of standard chemical compounds.

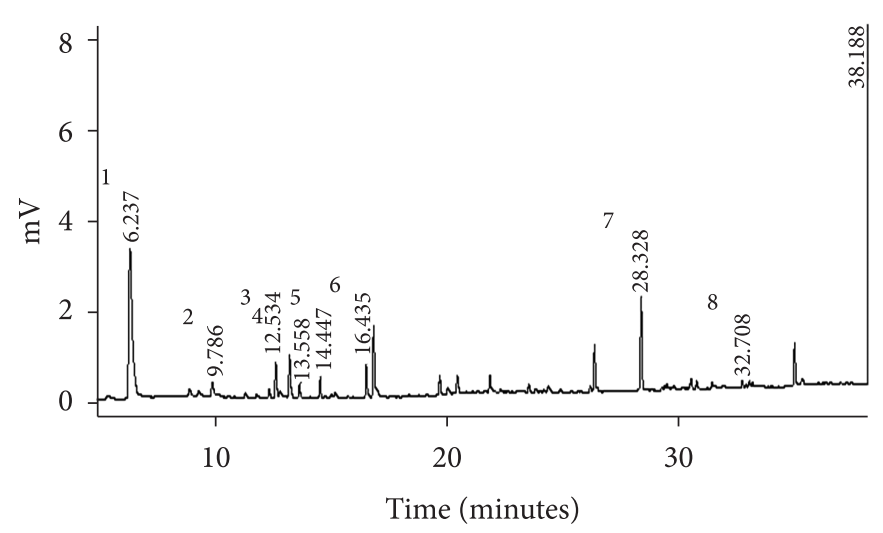

Figure 2. Typical chromatographic profile of $10^{\circ}$ Brix guava nectar sample.

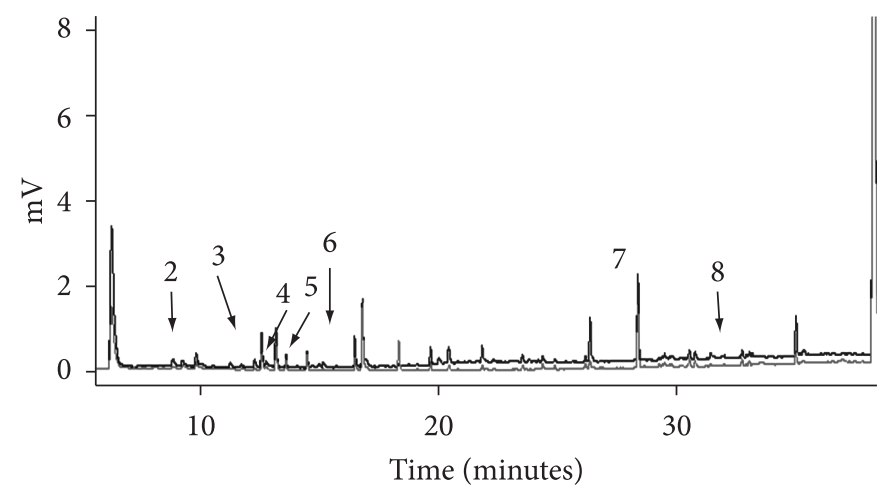

Figure 3. Gas chromatographic profile: black line is 1-C sample (guava nectar of $10^{\circ}$ Brix not pasteurized); gray line is 1-A sample (heat pasteurized $10^{\circ}$ Brix guava nectar) at day after processing (time zero).
Volatile compounds mean values found in heat pasteurized and not pasteurized guava nectar with 10,12 , or $14{ }^{\circ}$ Brix are presented in Table 2.

In Table 1 , it can be observed a significant effect $(\mathrm{p}<0.05)$ of formulation for $(E)$-hex-2-enal and $(Z)$-hex-3-enyl acetate. It can also be observed a significant effect of heat pasteurization only for hexanal and ( $Z$ )-hex-3-enyl acetate with a trend of decreasing these compounds level with pasteurization.

There is also a trend of increasing $(E)$-hex-2-enal as ${ }^{\circ}$ Brix of formulation increase (Table 2). The $12^{\circ} \mathrm{Brix}$ formula tend to have higher levels of $(Z)$-hex-3-enyl acetate. The hexanal losses, in concentration for nectar of 10,12 and $14^{\circ} \mathrm{Brix}$, were 55.4, 38.7 and $62.0 \%$, respectively. Losses of $(Z)$-hex-3-enyl acetate, for nectar of 10,12 and $14{ }^{\circ}$ Brix, were $29.0,33.7$ and $35.3 \%$, respectively. These findings lead to the conclusion that hexanal and $(Z$ )-hex-3-enyl acetate were the most sensitive to heat treatment at $85^{\circ} \mathrm{C} / 42$ sececonds among the eight compounds analyzed.

Janzantti (1996) found hexanal as the major volatile compound in clarified apple juice and the one with higher decrease in concentration after heat treatment of $80{ }^{\circ} \mathrm{C} / 20$ minutes. El-Nemr, Ismail and Askar (1988) observed a decrease in concentration of all volatile fractions in mango juice with processing, and they attributed this fact to evaporation, specially the esters fractions.

The mean values observed for guava nectar in this research, Table 2, for hexanal, 8 ng. $\mu \mathrm{L}^{-1}, 3$-phenylpropyl acetate, $4.65 \mathrm{ng} . \mu \mathrm{L}^{-1}$ and, cinnamyl acetate, $0.66 \mathrm{ng} . \mu \mathrm{L}^{-1}$ are similar to those found by Chyau, Chen and $\mathrm{Wu}$ (1992) in guava pulp. As for $(E)$-hex-2-enal, hexanal, $(Z)$-hex-3-enol and (Z)-hex-3-enyl acetate, the above mentioned authors reported higher values than those found in this research, 13.0, 2.7, 5.7, and $14.0 \mathrm{ng} . \mu \mathrm{L}^{-1}$, respectively. However, Ortega et al. (1998) reported values for 
hexanol, (Z)-hex-3-enol and (Z)-hex-3-enyl acetate and, also for 3-phenylpropyl in guava juice similar to those found in this research.

For guava nectar formulated with $40 \%$ of guava pulp, pasteurized at $85^{\circ} \mathrm{C} / 42$ sececonds, the mean values of volatiles detected, Table 2, may be considered as adequate for the product. Mean values of hexanal, hexanol and $(Z)$-hex-3-enyl acetate reported by Yen and Lin (1999) for guava juice were 0.021, 0.19, and $0.32 \mathrm{ng} . \mu \mathrm{L}^{-1}$, respectively. These values are lower than those found in this research for these compounds.

\subsection{Identification and quantification of guava nectar volatile compounds - effect of storage time, and temperature}

Figure 4 is a typical chromatogram of $14^{\circ} \mathrm{Brix}$ guava nectar at time zero (black line) as compared to similar sample after 120 days (gray line) of storage at room temperature, $25 \pm 5^{\circ} \mathrm{C}$. From this chromatogram, it seems that after 120 days of storage at $25 \pm 5^{\circ} \mathrm{C}$, under natural day light, the $14{ }^{\circ}$ Brix guava nectar had higher decrease of compounds hexanal, pick 1, (Z)-hex-3enyl acetate, pick 3, and, 3-phenylpropyl acetate, pick 7.

The analyses of variance of the volatile compounds data detected a significant effect $(\mathrm{p}<0.05)$ of formulation $\mathrm{x}$ storage

Table 2. Pasteurized and not pasteurized guava nectar volatile compounds mean values at day after processing (time zero of storaging).

\begin{tabular}{|c|c|c|c|c|c|c|c|c|}
\hline \multirow[t]{2}{*}{ Formulations } & \multicolumn{8}{|c|}{ Volatile compounds ${ }^{\star}\left(\right.$ ng. $\left.\mu L^{-1}\right)$} \\
\hline & 1 & 2 & 3 & 4 & 5 & 6 & 7 & 8 \\
\hline $10^{\circ} \operatorname{Brix}(1-C)^{S P}$ & 15.57 & 0.37 & 0.36 & 0.31 & 1.02 & 4.49 & 0.48 & 26.28 \\
\hline $12^{\circ} \operatorname{Brix}(2-C)^{\mathrm{SP}}$ & 15.72 & 0.73 & 0.29 & 0.25 & 1.57 & 4.88 & 0.56 & 20.13 \\
\hline $14^{\circ} \operatorname{Brix}(3-C)^{\mathrm{SP}}$ & 19.62 & 0.90 & 0.37 & 0.31 & 1.33 & 5.03 & 0.61 & 14.91 \\
\hline $10^{\circ} \operatorname{Brix}(1)^{p}$ & 6.94 & 0.38 & 0.33 & 0.32 & 0.72 & 4.56 & 0.63 & 20.36 \\
\hline $12^{\circ} \operatorname{Brix}(2)^{p}$ & 9.63 & 0.66 & 0.34 & 0.30 & 1.04 & 4.98 & 0.72 & 26.40 \\
\hline $14^{\circ} \operatorname{Brix}(3)^{\mathrm{P}}$ & 7.45 & 1.00 & 0.26 & 0.33 & 0.86 & 4.40 & 0.63 & 26.04 \\
\hline
\end{tabular}

temperature $\mathrm{x}$ storage time interaction only for (Z)-hex-3-enyl and 3-phenylpropyl acetates. There was a significant effect $(p>0.05)$ of this interaction on the other six compounds analyzed, Table 3 . There was no significant effect $(p>0.05)$ of storage time $\mathrm{x}$ temperature and formulation $\times$ storage temperature interactions for any of the eight compounds analyzed. Formulation $\mathrm{x}$ storage time interaction effect was significant $(\mathrm{p}<0.03)$ for $(\mathrm{Z})$-hex-3-enyl and cinnamyl acetates data.

The mean values of volatile compounds in guava nectar during storage (40, 80 , or 120 days) under refrigeration $(R)$ or room temperature $(\mathrm{A})$ are presented in Table 4 . A decrease in the volatile compound contents was more intense in guava nectar stored at room temperature. Major changes were observed in hexanal, (E)-hex-2-enal, cinnamyl acetate and acetic acid, Table 4. For the three formulations, the average of hexanal and (E)-hex-2-enal decreased 65.88 and $39.70 \%$ at 120 days storage at room temperature, respectively, as compared to data from time zero.

Yen and Lin (1999) reported decreases of 89.55 and $77.61 \%$ for hexanal in guava juice samples stored for 60 days under room or refrigeration temperature, respectively, as compared to time zero. In mango juice, El-Nemr, Ismail and Askar (1988) observed decreases in the main volatile compounds responsible for mango aroma during 120 days of storage at room temperature. In clarified apple juice, Janzantti (1996) observed an increase in hexanal concentration during showing how important for flavor stability refrigeration is 90 days of storage under room temperature. This may be due to the apple juice flavor deterioration by non enzymatic oxidation of saturated compounds.

In Table 4, it can be observed a very low decrease in (E)-hex2 -enal concentration in guava nectar stored for 120 days under refrigeration. This is a very interesting finding since (E)-hex-2enal is reported to be responsible for the fresh and typical guava flavor. A small decrease was observed in the hexanol content in guava nectar stored under room temperature, averaging $12.90 \%$,

Table 3. Mean square/error mean square and ( $\mathrm{p}$ value for $\mathrm{F}$ statistic) in analysis of variance data of volatile compounds in guava nectar stored for 120 days in guava nectar stored under refrigeration or at room temperature.

\begin{tabular}{|c|c|c|c|c|c|c|c|}
\hline $\begin{array}{l}\text { Source of } \\
\text { variation }\end{array}$ & Formulation & $\begin{array}{c}\text { Storage } \\
\text { temperature }\end{array}$ & $\begin{array}{l}\text { Storage } \\
\text { time }\end{array}$ & $\begin{array}{c}\text { Formulation } \times \\
\text { temperature }\end{array}$ & $\begin{array}{c}\text { Formulation } \times \\
\text { time }\end{array}$ & $\begin{array}{c}\text { Temperature } \times \\
\text { time }\end{array}$ & $\begin{array}{c}\text { Formulation } \times \\
\text { temperature } \times \text { time }\end{array}$ \\
\hline Compound/DF & 2 & 1 & 2 & 2 & 4 & 2 & 4 \\
\hline Hexanal & $\begin{array}{l}1.6874 / 2.0496 \\
(0.4908)\end{array}$ & $\begin{array}{l}111.7302 / 2.3277 \\
(0.0010)\end{array}$ & $\begin{array}{l}28.0044 / 1.4455 \\
(0.0001)\end{array}$ & $\begin{array}{l}1.5344 / 2.3277 \\
(0.5590)\end{array}$ & $\begin{array}{l}1.2419 / 1.4455 \\
(0.5052)\end{array}$ & $\begin{array}{l}0.3807 / 1.4455 \\
(0.7711)\end{array}$ & $\begin{array}{l}1.1951 / 1.4455 \\
(0.5237)\end{array}$ \\
\hline (E)-hex-2-enal & $\begin{array}{l}0.0707 / 0.0613 \\
(0.3877)\end{array}$ & $\begin{array}{l}0.4069 / 0.0517 \\
(0.0378)\end{array}$ & $\begin{array}{l}0.3223 / 0.0712 \\
(0.0239)\end{array}$ & $\begin{array}{l}0.0287 / 0.0517 \\
(0.6061)\end{array}$ & $\begin{array}{l}0.1094 / 0.0712 \\
(0.2300)\end{array}$ & $\begin{array}{l}0.0196 / 0.0712 \\
(0.7617)\end{array}$ & $\begin{array}{l}0.0367 / 0.0712 \\
(0.7316)\end{array}$ \\
\hline Hexanol & $\begin{array}{l}0.0305 / 0.0029 \\
(0.0165)\end{array}$ & $\begin{array}{l}0.0079 / 0.0053 \\
(0.0795)\end{array}$ & $\begin{array}{l}0.0028 / 0.0033 \\
(0.4442)\end{array}$ & $\begin{array}{l}0.0031 / 0.0053 \\
(0.2485)\end{array}$ & $\begin{array}{l}0.0039 / 0.0033 \\
(0.3492)\end{array}$ & $\begin{array}{l}0.0100 / 0.0033 \\
(0.0732)\end{array}$ & $\begin{array}{l}0.0027 / 0.0033 \\
(0.5330)\end{array}$ \\
\hline (Z)-hex-3-enol & $\begin{array}{l}0.0147 / 0.0013 \\
(0.0133)\end{array}$ & $\begin{array}{l}0.0043 / 0.0049 \\
(0.3933)\end{array}$ & $\begin{array}{l}0.0021 / 0.0026 \\
(0.4557)\end{array}$ & $\begin{array}{l}0.0003 / 0.0049 \\
(0.9324)\end{array}$ & $\begin{array}{l}0.0013 / 0.0026 \\
(0.7217)\end{array}$ & $\begin{array}{l}0.00001 / 0.0026 \\
(0.9942)\end{array}$ & $\begin{array}{l}0.0029 / 0.0026 \\
(0.3677)\end{array}$ \\
\hline $\begin{array}{l}\text { (Z)-hex-3-enyl } \\
\text { acetate }\end{array}$ & $\begin{array}{l}0.0137 / 0.0319 \\
(0.6714)\end{array}$ & $\begin{array}{l}0.5975 / 0.0053 \\
(0.0001)\end{array}$ & $\begin{array}{l}0.0827 / 0.0167 \\
(0.0181)\end{array}$ & $\begin{array}{l}0.0190 / 0.0053 \\
(0.1070)\end{array}$ & $\begin{array}{l}0.0578 / 0.0167 \\
(0.0268)\end{array}$ & $\begin{array}{l}0.0020 / 0.0167 \\
(0.8856)\end{array}$ & $\begin{array}{l}0.0845 / 0.0167 \\
(0.0056)\end{array}$ \\
\hline $\begin{array}{l}\text { 3-phenyilpropyl } \\
\text { acetate }\end{array}$ & $\begin{array}{l}1.4165 / 0.2044 \\
(0.0362)\end{array}$ & $\begin{array}{l}26.3525 / 0.2158 \\
(0.0001)\end{array}$ & $\begin{array}{l}6.9871 / 0.4173 \\
(0.0001)\end{array}$ & $\begin{array}{l}0.6258 / 0.2158 \\
(0.1458)\end{array}$ & $\begin{array}{l}0.5015 / 0.4173 \\
(0.3409)\end{array}$ & $\begin{array}{l}0.6594 / 0.4173 \\
(0.2306)\end{array}$ & $\begin{array}{l}1.4760 / 0.4173 \\
(0.0244)\end{array}$ \\
\hline $\begin{array}{l}\text { Cinnamyil } \\
\text { acetate }\end{array}$ & $\begin{array}{l}0.0427 / 0.0056 \\
(0.0308)\end{array}$ & $\begin{array}{l}0.6554 / 0.0063 \\
(0.0002)\end{array}$ & $\begin{array}{l}0.6035 / 0.0051 \\
(0.0001)\end{array}$ & $\begin{array}{l}0.0155 / 0.0063 \\
(0.1799)\end{array}$ & $\begin{array}{l}0.0324 / 0.0051 \\
(0.0018)\end{array}$ & $\begin{array}{l}0.0042 / 0.0051 \\
(0.4530)\end{array}$ & $\begin{array}{l}0.0041 / 0.0051 \\
(0.5285)\end{array}$ \\
\hline Acetic acid & $\begin{array}{l}895.4629 / 215.8784 \\
(0.0867)\end{array}$ & $\begin{array}{l}2300.8297 / 308.7829 \\
(0.0413)\end{array}$ & $\begin{array}{l}1099.5829 / 451.0078 \\
(0.1128)\end{array}$ & $\begin{array}{l}1118.6089 / 308.7829 \\
(0.1065)\end{array}$ & $\begin{array}{l}383.0926 / 451.0078 \\
(0.5106)\end{array}$ & $\begin{array}{l}117.2260 / 451.0078 \\
(0.7737)\end{array}$ & $\begin{array}{l}718.5110 / 451.0078 \\
(0.2150)\end{array}$ \\
\hline
\end{tabular}


almost the stability for guava nectar stored under refrigeration. Losses in (Z)-hex-3-enol were 15.63 and $18.75 \%$ for guava nectar samples stored under room or refrigerated, respectively. Among the volatile compounds analyzed, alcohols seemed to be the most stable. Yen and Lin (1999) reported greater decrease of hexanol in guava juice stored for 60 days under room temperature, $68.42 \%$, and only $5.26 \%$ for refrigeration storage.

Ester compounds were the most sensitive during the 120 days of storage period. Cynnamyl acetate, the most unstable, presented decreases of $60.91 \%\left(10^{\circ} \mathrm{Brix}\right), 71.61 \%\left(12{ }^{\circ} \mathrm{Brix}\right)$ and, $78.78 \%$ ( $\left.14^{\circ} \mathrm{Brix}\right)$ for guava nectar stored under room temperature at 120 days of storage as compared to data at

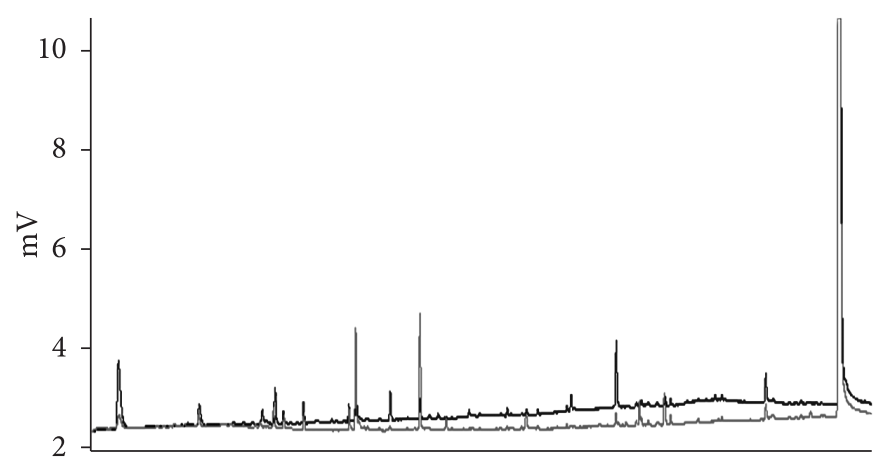

Figure 4. Gas chromatografic profile: black line is sample 3 (guava néctar of $14^{\circ} \mathrm{Brix}$ ) at time zero); gray line is 3-A sample (guava néctar of $14^{\circ}$ Brix) at 120 days stored at room temperature.

Table 4. Mean values for volatile compounds in guava nectar stored under room temperature conditions $(\mathrm{A})$ and under refrigeration $(\mathrm{R})$

\begin{tabular}{|c|c|c|c|c|c|c|c|c|}
\hline \multirow[t]{2}{*}{ Formulation } & \multicolumn{8}{|c|}{ Volatile compounds (ng. $\left.\mu \mathrm{L}^{-1}\right)$} \\
\hline & 1 & 2 & 3 & 4 & 5 & 6 & 7 & 8 \\
\hline \multicolumn{9}{|c|}{40 days storage } \\
\hline $10^{\circ} \operatorname{Brix}(1-\mathrm{A})$ & 5.25 & 0.63 & 0.31 & 0.30 & 38 & 2.84 & 0.35 & 29.55 \\
\hline 12 Brix (2-A) & 4.64 & 0.67 & 0.20 & 0.24 & 0.35 & 2.23 & 0.50 & 73.85 \\
\hline $14^{\circ} \mathrm{B}$ & 6.41 & 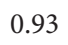 & 0.23 & 33 & 0.52 & 3.65 & 0.58 & 55.19 \\
\hline & & & & & & & 62 & \\
\hline $12{ }^{\circ} \mathrm{Bri}$ & 7.11 & 0.80 & 0.23 & 0.24 & 0.72 & 5.18 & 0.79 & 23.27 \\
\hline & & 0.99 & 0.34 & 0.26 & 0.41 & 3.78 & .81 & 20.02 \\
\hline \multicolumn{9}{|c|}{80 days storage } \\
\hline $10^{c}$ & & 0.60 & 036 & 0.33 & & & 12 & \\
\hline $12^{\circ} \mathrm{B}$ & 3.86 & 0 . & 0 . & 0.24 & 0.24 & 2.47 & 0.25 & 31.41 \\
\hline $14^{\circ} \mathrm{B}$ & 3.23 & 0.34 & 0.23 & 0.24 & 0.16 & 1.51 & 0.20 & 29.44 \\
\hline & & & & & & & 44 & \\
\hline $12^{\circ} \mathrm{B}$ & 6.11 & 0.83 & & 0.24 & 0.70 & 3.75 & 0.56 & 22.01 \\
\hline $14^{\circ} \mathrm{F}$ & 700 & 0.62 & 0.26 & 0.24 & 0.33 & 2.58 & 0.32 & 2181 \\
\hline \multicolumn{9}{|c|}{120 days storage } \\
\hline $10^{\circ} \mathrm{B}$ & 2.00 & 0.28 & 0.31 & 0.32 & 0.31 & $1.0 J$ & 0.15 & 35.19 \\
\hline$(2-A)$ & 3.32 & 0.65 & 0.26 & 0.27 & 0.32 & 1.56 & 0.15 & 37.46 \\
\hline $14^{\circ}$ Brix (3-A) & 2.32 & 0.31 & & & 0.33 & & 0.11 & 33.68 \\
\hline $10^{\circ} \operatorname{Brix}(1-\mathrm{R})$ & 5.07 & 0.44 & 0.33 & 0.29 & 0.52 & 2.64 & 0.33 & 24.14 \\
\hline 12 oBrix (2-R) & 5.42 & 0.69 & 0.33 & 0.23 & 0.65 & 3.34 & 0.42 & 18.44 \\
\hline 14 Brix (3-R) & 6.66 & 0.78 & 0.27 & 0.26 & 0.76 & 3.81 & 0.26 & 12.07 \\
\hline
\end{tabular}

$1=$ Hexanal; $2=(E)$-hex-2-enal; $3=$ hexanol; $4=(Z)$-hex-3-enol; $5=(Z)$-hex-3-enyl acetate; $6=3$-phenylpropyl acetate; $7=$ cynnamyl acetate; and $8=$ acetic acid. time zero. (Z)-hex-3-enyl acetate, 3-phenylpropyl acetate and cinnamyl acetate, the averages for the three formulations lost $26.44,29.90$ and, $48.48 \%$, respectively, for guava nectar stored under refrigeration for 120 days, as compared to data at time zero.

Yen and Lin (1999) reported 56.25 and 6.25\% decreases in concentration of (Z)-hex-3-enyl acetate in guava juice stored at room temperature and refrigeration, respectively. Sandi (1999) reported decreases averaging of $80 \%$ for ester compounds in heat treated, $85{ }^{\circ} \mathrm{C} / 27$ seconds, for passion fruit juice after 120 days storage. Room temperature was again responsible for greater losses.

Shibamoto and Tang (1990) stated that esters make up a group of compounds of high aromatic, pleasant and typical of guava, even when present in very low levels. They considered cinnamyl acetate as the most important compound contributing for the sweet floral aroma in guava ripe fruit.

Acetic acid was presented the highest concentration in the guava nectar among the eight compounds analyzed in this research, Table 4, with almost no variation during storage for 120 days, either at room temperature or refrigeration. Yen, Lin and Yang (1992) studying guava puree for six months under frozen condition observed small increases in decanoic and dodecanoic acids and also in ethanol contents. They suggested enzymatic oxidation reactions as possible causes for this fact.

Idstein and Schreier (1995) studied acid compounds in guava skin, pulp, and guava puree. They identified 51 of these compounds, among them, acetic acid. In highest concentration, they identified $(Z)$-3-hexenoic and $(Z)$-cinnamyc acids. They also suggested that acid compounds do not contribute to guava aroma, even in higher concentrations. However, Shibamoto and Tang (1990) suggested that low molecular weight acid compounds, such as the $\mathrm{C}^{2}$ to $\mathrm{C}^{8}$, may contribute slightly for guava aroma.

\section{Conclusion}

Solid Phase Micro Extraction technique (SPME) together with Gas Chromatography and, Gas Chromatography linked to Mass Spectrometry were efficient in the identification and quantification of hexanal, $(E)$-hex-2-enal, 1-hexenol, (Z)-hex-3-enal and, $(Z)$-hex-3-enyl, 3-phenylpropyl and cinamyl acetates and acetic acid in guava nectar. There was good repeatability with similar chromatogram profile for several samples. All the eight compounds were affected by heat treatment. Hexanal and $(Z)$-hex-3-enyl acetate were considered the most sensitive since they presented higher decrease. After 120 days of storage, the decrease in concentration of all eight compounds, at room temperature condition, was more damaging , $(E)$-hex-2-enal and hexanal presented lower decrease in concentration during storage for 120 days. Esters compounds were the most sensitive to storage time presenting, proportionally, higher decreases. Cinnamyl acetate seemed to be the most sensitive to storage time. Acetic acid had the highest concentration. Refrigeration storage for 120 days was better for volatile compounds stability in guava nectar. 


\section{References}

ASKAR, A.; El-NEMR, I.; BASSIOUNY, S. S. La guayaba y otras frutas tropicales. Alimentaria, v. 25, n. 6, p. 162-167, 1986.

BENÉ, A. et al. A new method for the rapid determination of volatile substances: the SPME-direct method. Part I: apparatus and working conditions. Sensors and actuators B, v. 72, p. 184-187, 2001.

BJELEN, H. H. et al. Solid-phase microextraction for the analysis of some alcohols and esters in beer: comparison with static headspace method. Journal Agriculture Food Chemistry, v. 46, n. 4, p. 1469-1473, 1998.

CLARA, E. et al. Constituyentes volátiles das variedades de guayaba (Psidium guajava L.): Palmira ICA-1 y Glum Sali. Revista Colombiana de Química, v. 28, n. 1, 1999.

CHYAU, C. C.; CHEN, S. Y.; WU, C. M. Differences of volatile and nonvolatile constituents between mature and ripe guava ((Psidium guajava L.) fruits. Journal Agricultural Food Chemistry, v. 40, p. 846-849, 1992.

EL-NEMR, S. E.; ISMAIL, 1. A.; ASKAR, A. Aroma changes in mango juice during processing and storage. Food Chemistry, v. 38, p. 269-275, 1988.

FELLOWS, P. Food processing technology: principles and practice. Abington: Woodhead, 1997.

IDSTEIN, H.; SCHREIER, P. Volatile constituents from guava (Psidium guajava L.) fruit. Journal Agricultural Food Chemistry, v. 33, p. 138-143, 1985.

JANZANTTI, N. S. I. Composição de voláteis de maçãs (Malus domestica) cultivar fuji II. Efeito do processamento e do armazenamento na composição de voláteis de suco clarificado de maçãs fuji. 1996. 179 f. Dissertação (Mestrado em Ciência de Alimentos)-Faculdade de Engenharia de Alimentos, Universidade Estadual de Campinas, Campinas, 1996.

JORDAN, M. J. et al. Volatile components and aroma active compounds in aqueous essence and fresh pink guava fruit puree (Psidium guajava, L.) by GC-MS and multidimensional GC/GC-O. Journal Agricultural Food Chemistry, v. 51, n. 5, p. 1421-1426, 2003.

KATAOKA, H.; LORD, H. L.; PAWLISZYN, J. Review - Applications of solid-phase microextraction in food analysis. Journal of Chomatography A, v. 880, p. 35-62, 2000.

MANICA, I. et al. Fruticultura tropical 6: goiaba. Porto Alegre: Cinco Continentes, 2000.

MORAlES, J. O. Z. Processamento de suco de abacaxi [Ananás comosus (L.) Merrill]: qualidade sensorial e físico-química. 1999. 94 f. Dissertação (Mestrado em Ciência e Tecnologia de Alimentos)Universidade Federal de Viçosa, Viçosa, 1999.

NILSSON, T.; FERRARI, R.; FACCHETTI, S. Inter-laboratory studies for the validation of solid-phase microextraction for the quantitative analysis of volatile organic compounds in aqueous samples. Analytica Chimica ACTA, v. 356, p. 113-123, 1997.

NISHIMURA, O. et al. Volatile constituents of guava fruits ((Psidium guajava L.) and canned puree. Journal Agricultural Food Chemistry, v. 37, p. 139-142, 1989.
NOBREGA, I. C. A. Análise dos compostos voláteis da aguardente de cana por concentração dinâmica do "headspace" e cromatografia gasosa - espectrometria de massas. Ciência e Tecnologia de Alimentos, v. 23, n. 2, p. 210-216, 2003.

ORTEGA, A. G. et al. Estudio de los componentes volatiles y perfil sensorial de cuatro cultivares de guayaba (Psidium guajava L.). Alimentaria, p. 31-35, 1998.

ORTEGA, A. G.; PINO, J. A. Los constituyentes volátiles de la guayaba (Psidium guajava L.). Alimentaria, v. 276, p. 65-72, 1996.

PINO, J.A.; MARBOT, R.; VASQUES, C. Characterization of volatiles in Costa Rican guava [Psidium friedrichsithalianum (Berg) Niedenzu] fruit. Journal of Agricultural and Food Chemistry, v. 50, p. 6023-6026, 2002.

SANDI, D. Efeito do tratamento térmico e do armazenamento sobre a qualidade sensorial do suco de maracujá-amarelo [Passiflora edulis var. flavicarpa].1999. 153 f. Dissertação (Mestrado em Ciência e Tecnologia de Alimentos)-Universidade Federal de Viçosa, Viçosa, 1999.

SHAW, P. E.; BERRY, R. E. Hexose-amino acid degradation studies involving formation of pyrroles, furans and low molecular weight products. Journal of Agricultural and Food Chemistry, v. 25, n. 3, p 641-644, 1976.

SHIBAMOTO, T.; TANG, C. S. 'Minor' tropical fruits - mango, papaya, passion fruit and guava. In: MORTON, I. D; MACLEOD, A. J. (Eds.). Food flavours. Part C: the flavour of fruits. 1990. Chap. VI, p. 221-280.

SONG, J. et al. Rapid analysis of volatile flavor compounds in apple fruit using SPME and GC/time-of-flight mass spectrometry. Journal of Agricultural and Food Chemistry, n. 45, p. 1801-1807, 1997.

STATISTICAL ANALYSES SYSTEM - SAS. User's guide: basic and statistic. Cary: 1995. 1686 p.

TCHANGO-TCHANGO, J. et al. Heat resistance of the spoilage yeasts Candida pelliculosa and Kloeckera apis and pasteurization values for some tropical fruit juices and nectars. Food Microbiology, v. 14, n.1, p. 93-99, 1997.

VALENTE, A. L. P.; AUGUSTO, F. Microextração de fase sólida. Química Nova, v. 23, n. 4, p. 522-530. 2000.

YANG, X.; PEPPARD, T. Solid-phase microextraction for flavor analysis. Journal of Agricultural and Food Chemistry, v. 42, p. 1925-1930, 1994.

YEN, G. C.; LIN, H. T. Changes in volatile flavor components of guava juice with high-pressure treatment and heat processing and during storage. Journal of Agricultural and Food Chemistry, v. 47, p. 2082-2087, 1999.

YEN, G. C.; LIN, H. T.; YANG, P. Volatile constituents of guava fruits (Psidium guajava L.) and canned puree. Journal of Food Science, v. 57, n. 3 , p. $679-681,1992$. 